\title{
An alternative total synthesis of solamargine
}

\author{
WEI GuoHua, WEI DongBin* \& DU YuGuo* \\ State Key Laboratory of Environmental Chemistry and Ecotoxicology; Research Center for Eco-Environmental Sciences (CAS), \\ Beijing 100085, China
}

Received October 10, 2011; accepted October 14, 2011; published online January 5, 2012

\begin{abstract}
Solamargine, $\quad(25 R)-3 \beta-\{O$ - $\alpha$-L-rhamnopyranosyl-( $1 \rightarrow 2)-[O-\alpha$-L-rhamnopyranosyl-( $1 \rightarrow 4)]-\beta$-D-glucopyranosyloxy $\}-22 \alpha-N$ spirosol-5-ene, isolated from the berries of solanum aculeastrum, has been synthesized in $26.8 \%$ overall yield. First glycosylation before $N$-cyclization significantly facilitated synthesis of the desired molecule. We anticipate that this work will provide a new approach to access solamargine and its diversified analogues.
\end{abstract}

solasodine, natural products, solamargine, glycosides

\section{Introduction}

Solamargine is a major glycoalkaloid which occurs in at least 100 Solanum species [1]. Pharmacological studies have indicated that solamargine and its derivatives show anti-tumor activities through inhibition of tumor cell growth, such as colon (HT-29, HCT-15), prostate (LNCap, PC-3), breast (T47D, MDA-MB-231), and human hepatoma (PLC/PRF/5) cells [2-6]. Despite its widespread occurrence and biological importance, there are surprisingly few reports of the total synthesis of solamargine or structurally related compounds [7]. Recently, we reported the total synthesis of solamargine using partially protected glucopyranosyl donor and an oxaza-spiro moiety in 13 steps in a $10.5 \%$ overall yield. The synthetic solamargine exhibited good cytotoxic activities against tumor cells HeLa, A549, MCF-7, K562, HCT116, U87, and HepG2 with IC50 ranging from 2.1 to $8.0 \mu \mathrm{M}$ [8]. To further investigate the preclinical potential, we need a practical method toward large scale preparation of solamargine. Herein we would like to report our solution for this purpose.

*Corresponding author (email: weidb@rcees.ac.cn; duyuguo@ rcees.ac.cn)

\section{Experimental}

\section{General methods}

Optical rotations were determined at $25^{\circ} \mathrm{C}$ with a PerkinElmer Model 241-Mc automatic polarimeter unless otherwise stated. ${ }^{1} \mathrm{H},{ }^{13} \mathrm{C}$ NMR spectra were recorded with ARX 400 spectrometers for solutions in $\mathrm{CDCl}_{3}$ or $\mathrm{CD}_{3} \mathrm{OD}$. Chemical shifts are given in ppm downfield from internal $\mathrm{Me}_{4} \mathrm{Si}$. Mass spectra were measured using MALDI-TOFMS with dihydroxybenzoic acid (DHB) as the matrix. High-resolution mass spectrometry was conducted in a positive mode using ESI-source. Thin layer chromatography (TLC) was performed on silica gel $\mathrm{HF}_{254}$ with detection by charring with $30 \%(v / v) \mathrm{H}_{2} \mathrm{SO}_{4}$ in $\mathrm{MeOH}$ or in some cases by a UV detector.

\section{Synthesis of compound 5}

Compound 2 (185 $\mathrm{mg}, 0.38 \mathrm{mmol}$ ) was subjected to $\mathrm{Ac}_{2} \mathrm{O} / \mathrm{Py}$. After removal of the solvent, the residue was dissolved into wet acetone $(2 \mathrm{~mL})$, and NBS (136 mg, 0.76 mmol) was added at $-10{ }^{\circ} \mathrm{C}$. Then, the reaction mixture was stirred for $30 \mathrm{~min}$ in the dark, concentrated, and extracted with methylene chloride $(3 \times 20 \mathrm{~mL})$. The organic phase was washed successively with saturated aqueous $\mathrm{NaHCO}_{3}$, brine, then dried over anhydrous $\mathrm{Na}_{2} \mathrm{SO}_{4}$ and concentrated 
to dryness, and then the residue was subjected to DBU/ $\mathrm{Cl}_{3} \mathrm{CCN}$. Purification of the residue by silica-gel column chromatography (3:1 petroleum ether-EtOAc) afforded $\mathbf{5}$ (202 mg, 88\% for 3 steps); $[\alpha]_{\mathrm{D}}{ }^{25}-28\left(c 2.4, \mathrm{CHCl}_{3}\right) ;{ }^{1} \mathrm{H}$ NMR (400 MHz, $\left.\mathrm{CDCl}_{3}\right): 1.92,2.01\left(2 \mathrm{~s}, 2 \times 3 \mathrm{H}, \mathrm{CH}_{3} \mathrm{CO}\right)$, $3.47-3.55(\mathrm{~m}, 2 \mathrm{H}), 3.80\left(2 \mathrm{~s}, 2 \times 3 \mathrm{H}, \mathrm{CH}_{3} \mathrm{OPhCH}_{2}\right)$, 4.03-4.07 (m, $2 \mathrm{H}), 4.44$ (q, $\left.2 \mathrm{H}, \mathrm{CH}_{3} \mathrm{OPhCH}_{2}\right), 4.60$ (q, 2 $\left.\left.\mathrm{H}, \mathrm{CH}_{3} \mathrm{OPhCH}\right)_{2}\right), 5.06(\mathrm{dd}, 1 \mathrm{H}, J 3.5,10.0 \mathrm{~Hz}, \mathrm{H}-2), 5.22(\mathrm{t}$, $1 \mathrm{H}, J 10.0 \mathrm{~Hz}, \mathrm{H}-4), 6.54(\mathrm{~d}, 1 \mathrm{H}, J 3.4 \mathrm{~Hz}, \mathrm{H}-1)$, 6.53-7.24 (m, $8 \mathrm{H}, P h), 8.61(\mathrm{~s}, 1 \mathrm{H}, \mathrm{NH}) .{ }^{13} \mathrm{C}$ NMR $(100$ $\left.\mathrm{MHz}, \mathrm{CDCl}_{3}\right): 20.5,20.7,55.2,55.23,68.3,69.9,71.8$, 72.18, 73.1, 74.1, 75.9, 90.9, 93.5, 159.2, 159.3, 160.7, 169.2, 169.7. MALDI-TOF-MS calcd for $\mathrm{C}_{28} \mathrm{H}_{32} \mathrm{Cl}_{3} \mathrm{NO}_{10}$ : $647.1[\mathrm{M}]^{+}$; found, $670.2[\mathrm{M}+\mathrm{Na}]^{+}$.

\section{Synthesis of compound 7}

To the solution of $6(100 \mathrm{mg}, 0.14 \mathrm{mmol})$ in dried pyridine $(3 \mathrm{~mL})$ was added HF-Py complex $(0.8 \mathrm{~mL})$ at $0{ }^{\circ} \mathrm{C}$. The mixture was stirred for $10 \mathrm{~h}$, and extracted with methylene chloride $(3 \times 20 \mathrm{~mL})$. The organic phase was washed successively with saturated aqueous $\mathrm{NaHCO}_{3}, 1 \mathrm{~N} \mathrm{HCl}$, saturated aqueous $\mathrm{NaHCO}_{3}$, brine, then dried over anhydrous $\mathrm{Na}_{2} \mathrm{SO}_{4}$ and concentrated. The residue was subjected to column chromatography on a silica gel column with 3:1 petroleum ether-EtOAc as the eluent to yield $\mathbf{7}$ as an amorphous solid $(55 \mathrm{mg}, 85 \%)$; $[\alpha]_{\mathrm{D}}{ }^{25}-54\left(c 2.1, \mathrm{CHCl}_{3}\right)$. Selected ${ }^{1} \mathrm{H}$ NMR (400 MHz, $\mathrm{CDCl}_{3}$ ): $0.78\left(\mathrm{~s}, 3 \mathrm{H}, \mathrm{CH}_{3}\right), 0.98$ (d, $\left.3 \mathrm{H}, J 6.5 \mathrm{~Hz}, \mathrm{CH}_{3}\right), 1.03\left(\mathrm{~m}, 6 \mathrm{H}, \mathrm{CH}_{3}\right), 2.55-2.62(\mathrm{~m}$, $3 \mathrm{H}), 2.75-2.82(\mathrm{~m}, 1 \mathrm{H}), 3.16(\mathrm{dd}, 1 \mathrm{H}, J 5.4,12 \mathrm{~Hz}$, H-26a), 3.27 (dd, $1 \mathrm{H}, J$ 5.4, $12 \mathrm{~Hz}, \mathrm{H}-26 \mathrm{~b}), 3.54(\mathrm{~m}, 1 \mathrm{H}$, $\mathrm{H}-3 \alpha$ ), 5.35 (d, $1 \mathrm{H}, J 5.1 \mathrm{~Hz}, \mathrm{H}-6) .{ }^{13} \mathrm{C}$ NMR $(100 \mathrm{MHz}$, $\left.\mathrm{CDCl}_{3}\right): 12.9,15.3,17.6,19.3,20.5,27.4,29.63,30.9,31.7$, $32.9,36.5,36.9,37.2,38.6,39.6,41.6,42.1,43.8,49.4$,

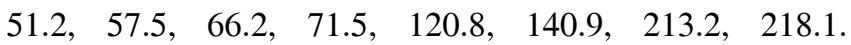
ESI-HRMS calcd for $\mathrm{C}_{27} \mathrm{H}_{41} \mathrm{~N}_{3} \mathrm{O}_{3}: 455.3148[\mathrm{M}]^{+}$; found, $456.3221[\mathrm{M}+\mathrm{H}]^{+}$.

\section{Synthesis of compound 8}

To a solution of compound 5 (170 $\mathrm{mg}, 0.26 \mathrm{mmol})$ and compound $7(80 \mathrm{mg}, 0.18 \mathrm{mmol})$ in anhydrous $\mathrm{CH}_{2} \mathrm{Cl}_{2}(2$ $\mathrm{mL}$ ) at $-15{ }^{\circ} \mathrm{C}$ was added AgOTf $(20 \mathrm{mg}, 0.08 \mathrm{mmol})$ under $\mathrm{N}_{2}$ protection. The mixture was stirred under these conditions for $80 \mathrm{~min}$, at the end of which TLC indicated the reaction was complete. The mixture was neutralized with $\mathrm{Et}_{3} \mathrm{~N}$ and concentrated to dryness. The residue was purified by column chromatography on a silica gel column with $3: 1$ petroleum ether-EtOAc as the eluent to yield $\mathbf{8}$ as an amorphous solid (155 mg, 94\%); $[\alpha]_{\mathrm{D}}^{25}-64\left(c 0.9, \mathrm{CHCl}_{3}\right)$. Selected ${ }^{1} \mathrm{H}$ NMR (400 MHz, $\mathrm{CDCl}_{3}$ ): 0.79 (s, $3 \mathrm{H}, \mathrm{CH}_{3}$ ), 0.94 $\left(\mathrm{d}, 3 \mathrm{H}, J 6.5 \mathrm{~Hz}, \mathrm{CH}_{3}\right), 1.04\left(\mathrm{~m}, 6 \mathrm{H}, \mathrm{CH}_{3}\right), 1.92,2.01(2 \mathrm{~s}$, $\left.2 \times 3 \mathrm{H}, \mathrm{CH}_{3} \mathrm{CO}\right), 2.55-2.61(\mathrm{~m}, 3 \mathrm{H}), 2.76(\mathrm{~m}, 1 \mathrm{H}), 3.17(\mathrm{dd}$, $1 \mathrm{H}, J 5.4,12 \mathrm{~Hz}, \mathrm{H}-26 \mathrm{a}), 3.27$ (dd, $1 \mathrm{H}, J 5.4,12 \mathrm{~Hz}$, H-26b), 3.44-3.55 (m, 4 H, H-3 $\left.\alpha, 6 \mathrm{a}^{\mathrm{I}}, 6 \mathrm{~b}^{\mathrm{I}}, 5^{\mathrm{I}}\right), 3.66$ (t, $1 \mathrm{H}, J$ $\left.9.4 \mathrm{~Hz}, \mathrm{H}-3^{\mathrm{I}}\right), 3.78\left(2 \mathrm{~s}, 2 \times 3 \mathrm{H}, \mathrm{CH}_{3} \mathrm{OPhCH}_{2}\right), 4.48(\mathrm{~m}, 5$
$\left.\mathrm{H}, J_{1}{ }_{1}^{\mathrm{I}}{ }_{2}^{\mathrm{I}} 8.0 \mathrm{~Hz}, \mathrm{CH}_{3} \mathrm{OPhCH}, \mathrm{H}-1^{\mathrm{I}}\right), 5.0\left(\mathrm{~m}, 2 \mathrm{H}, \mathrm{H}-2^{\mathrm{I}}, 4^{\mathrm{I}}\right)$, $5.32(\mathrm{~d}, 1 \mathrm{H}, J 5.0 \mathrm{~Hz}, \mathrm{H}-6), 6.82-7.25(\mathrm{~m}, 8 \mathrm{H}, P h)$. Selected ${ }^{13} \mathrm{C}$ NMR $\left(100 \mathrm{~Hz}, \mathrm{CDCl}_{3}\right)$ : 13.0, 15.4, 17.7, 19.4, $20.5,20.9,20.9,27.5,29.7,30.9,31.8,32.9,36.8,36.9$, $37.2,38.6,39.6,41.7,42.2,43.4,49.8,51.3,55.3(2 \mathrm{C})$, 57.6, 66.3, 69.7, 71.0, 72.8, 72.9, 73.3, 73.6, 79.5, 79.7, 99.9, 121.1, 140.8, 159.2, 159.3, 169.2, 169.6, 213.2, 218.1. ESI-HRMS calcd for $\mathrm{C}_{53} \mathrm{H}_{71} \mathrm{~N}_{3} \mathrm{O}_{12}: 941.5038[\mathrm{M}]^{+}$; found, $942.5111[\mathrm{M}+\mathrm{H}]^{+}$.

\section{Synthesis of compound 11}

The mixture of $8(80 \mathrm{mg}, 0.09 \mathrm{mmol})$ and $\mathrm{NaBH}_{4}(100$ $\mathrm{mg}, 2.63 \mathrm{mmol})$ in $i$-propanol $(2 \mathrm{~mL})$ and $\mathrm{CH}_{2} \mathrm{Cl}_{2}(0.2 \mathrm{~mL})$ was stirred at room temperature for $10 \mathrm{~h}$. The reaction mixture was then extracted with methylene chloride $(3 \times 20$ $\mathrm{mL}$ ). The organic phase was washed successively with saturated aqueous $\mathrm{NaHCO}_{3}$, brine, then dried over anhydrous $\mathrm{Na}_{2} \mathrm{SO}_{4}$ and concentrated. The residue was subjected to column chromatography on a silica gel column with $3: 1$ petroleum ether-EtOAc as the eluent to yield crude foamy 9 $(50 \mathrm{mg})$. To the solution of $9(50 \mathrm{mg}, 0.05 \mathrm{mmol})$ in THF (3 $\mathrm{mL})$ and $\mathrm{H}_{2} \mathrm{O}(0.3 \mathrm{~mL})$ was added $\mathrm{Ph}_{3} \mathrm{P}(41.7 \mathrm{mg}, 0.16$ mmol). The mixture was refluxed for $4 \mathrm{~h}$, and then co-evaporated with toluene to dryness to yield 10, which was used in the next step without further purification. Compound $\mathbf{1 0}$ was dissolved into a mixed solvent $(5 \mathrm{~mL}$, $\mathrm{CH}_{2} \mathrm{Cl}_{2}: \mathrm{MeOH}=1: 3$ ) and $\mathrm{NaOMe}$ was added at room temperature to make the $\mathrm{pH}$ around 10 . The above mixture was stirred at room temperature for $36 \mathrm{~h}$, and neutralized with Amberlite IR-120 $\left(\mathrm{H}^{+}\right)$resin. The liquid phase was evaporated in vacuo and the residue was purified on silica gel column chromatography with 1:2 petroleum ether-EtOAc $\rightarrow$ EtOAc as the eluent to yield $\mathbf{1 1}$ as an amorphous solid (38 mg, 53\% from 8); $[\alpha]_{\mathrm{D}}{ }^{25}-43\left(c 0.55, \mathrm{CHCl}_{3}\right)$. Selected ${ }^{1} \mathrm{H}$ NMR $\left(400 \mathrm{~Hz}, \mathrm{CDCl}_{3}\right): \delta 0.81$ (s, 3H, H-18), 0.86 (d, 3H, $J$ $=6.2 \mathrm{~Hz}, \mathrm{H}-27), 0.96$ (d, 3H, $J=7.2 \mathrm{~Hz}, \mathrm{H}-21), 1.03$ (s, 3H, H-19), 2.60-2.66 (m, 2H, H-26a, H-26b), 3.36-3.49 (m, 3H), 3.55-3.60 (m, 2H), $3.66\left(\mathrm{dd}, 1 \mathrm{H}, J=5.4,10 \mathrm{~Hz}, \mathrm{H}-6 \mathrm{a}^{\mathrm{I}}\right)$, $3.72\left(\mathrm{dd}, 1 \mathrm{H}, J=5.4,10 \mathrm{~Hz}, \mathrm{H}-6 \mathrm{~b}^{\mathrm{I}}\right), 3.80(\mathrm{~s}, 6 \mathrm{H}$, $\left.\mathrm{CH}_{3} \mathrm{OPhCH}_{2}\right), 4.32(\mathrm{~m}, 1 \mathrm{H}, \mathrm{H}-16), 4.36\left(\mathrm{~d}, 1 \mathrm{H}, J_{1,2}^{\mathrm{I}} \mathrm{I}=7.8\right.$ $\left.\mathrm{Hz}, \mathrm{H}-1^{\mathrm{I}}\right), 4.50\left(\mathrm{~s}, 2 \mathrm{H}, \mathrm{CH}_{3} \mathrm{OPhCH}_{2}\right), 4.72(\mathrm{~d}, 1 \mathrm{H}, J=11$ $\mathrm{Hz}$, one proton of $\left.\mathrm{CH}_{3} \mathrm{OPhCH}_{2}\right), 4.88(\mathrm{~d}, 1 \mathrm{H}, J=11 \mathrm{~Hz}$, one proton of $\mathrm{CH}_{3} \mathrm{OPhCH}$ ), $5.34(\mathrm{~d}, 1 \mathrm{H}, J=5.0 \mathrm{~Hz}, \mathrm{H}-6)$, 6.85-7.32 (m, 8H, Ph); Selected ${ }^{13} \mathrm{C}$ NMR $\left(100 \mathrm{~Hz}, \mathrm{CDCl}_{3}\right)$ : $\delta$ 15.4, 16.3, 19.2, 19.4, 20.9, 29.6, 29.7, 31.2, 31.4, 31.8, $32.1,32.2,36.9,37.3,38.9,39.8,40.6,42.4,47.7,50.1$, 55.3 (2 C), 56.4, 62.9, 70.3, 71.8, 73.3, 74.1, 74.1, 74.3, 79.1, 83.4 (2 C), 98.4, 101.3, 121.8, 140.4, 159.3, 159.4. ESI-HRMS calcd for $\mathrm{C}_{49} \mathrm{H}_{69} \mathrm{NO}_{9}$ : $815.4972[\mathrm{M}]^{+}$, found: $816.5046[\mathrm{M}+\mathrm{H}]^{+}$.

\section{Synthesis of compound 13}

Compounds 11 (22 mg, $0.03 \mathrm{mmol}$ ) and $\mathbf{1 2}(35 \mathrm{mg}, 0.10$ mmol) and activated $4 \AA$ molecular sieves were pre-dried in 
one flask under vacuum for $4 \mathrm{~h}$. The mixture was then dissolved in $\mathrm{CH}_{2} \mathrm{Cl}_{2}(1 \mathrm{~mL})$, and $\mathrm{AgOTf}(30 \mathrm{mg}, 0.12 \mathrm{mmol})$ and 2,6-lutidine $(15 \mu \mathrm{L}, 0.12 \mathrm{mmol})$ were added under an $\mathrm{N}_{2}$ atmosphere at $-30{ }^{\circ} \mathrm{C}$. The mixture was stirred under these conditions for $3 \mathrm{~h}$, neutralized with triethylamine, concentrated under reduced pressure, and purified on a silica gel column with 1:2 petroleum ether-EtOAc $\rightarrow$ EtOAc as the eluent to yield $\mathbf{1 3}$ as a white solid (30 mg, 90\%); $[\alpha]_{\mathrm{D}}{ }^{25}$ +68 (c 0.6, $\left.\mathrm{CHCl}_{3}\right)$. Selected ${ }^{1} \mathrm{H}$ NMR $\left(400 \mathrm{~Hz}, \mathrm{CDCl}_{3}\right): \delta$ 0.81 (s, 3H, H-18), 0.88 (d, 3H, $J=6.2 \mathrm{~Hz}, \mathrm{H}-27), 1.01$ (m, $6 \mathrm{H}, \mathrm{H}-21,19), 1.19-1.26$ (m, 6H, H-6 $\left.{ }^{\mathrm{II}}, 6^{\mathrm{III}}\right), 1.71,1.72$, $1.87,2.01,2.03,2.05\left(6 \mathrm{~s}, 6 \times 3 \mathrm{H}, \mathrm{CH}_{3} \mathrm{CO}\right), 2.62-2.68(\mathrm{~m}$, 2H, H-26a, H-26b), 3.36-3.57 (m, 7H), 3.67-3.72 (m, 2H), $3.78\left(2 \mathrm{~s}, 2 \times 3 \mathrm{H}, \mathrm{CH}_{3} \mathrm{OPhCH}_{2}\right), 4.32-4.34$ (m, 1H, H-16), $4.39\left(\mathrm{~d}, 2 \mathrm{H}, J_{1,2}^{\mathrm{I}}=7.8 \mathrm{~Hz}, \mathrm{H}-1^{\mathrm{I}}\right), 4.48(\mathrm{~s}, 2 \mathrm{H}$, $\mathrm{CH}_{3} \mathrm{OPhCH}$ ), $4.57(\mathrm{~d}, 1 \mathrm{H}, J=10.0 \mathrm{~Hz}$, one proton of $\mathrm{CH}_{3} \mathrm{OPhCH}$ ), 4.63 (dd, $1 \mathrm{H}, J=2.6,4.0 \mathrm{~Hz}, \mathrm{H}-2^{\mathrm{II}}$ ), 4.68 $\left(\mathrm{dd}, 1 \mathrm{H}, J=2.6,4.0 \mathrm{~Hz}, \mathrm{H}-2^{\mathrm{III}}\right), 4.74(\mathrm{~d}, 1 \mathrm{H}, J=10.0 \mathrm{~Hz}$, one proton of $\mathrm{CH}_{3} \mathrm{OPhCH}$ ), 4.98-5.04 (m, 3H, H-3 ${ }^{\mathrm{III}}, 4^{\mathrm{II}}$, $\left.4^{\mathrm{III}}\right), 5.10\left(\mathrm{dd}, 1 \mathrm{H}, J=4.0,8.6 \mathrm{~Hz}, \mathrm{H}-3^{\mathrm{II}}\right), 5.19(\mathrm{~d}, 1 \mathrm{H}, J=$ $\left.2.0 \mathrm{~Hz}, \mathrm{H}-1^{\mathrm{II}}\right), 5.23\left(\mathrm{~d}, 1 \mathrm{H}, J=2.0 \mathrm{~Hz}, \mathrm{H}-1^{\mathrm{III}}\right), 5.34(\mathrm{~d}, 1 \mathrm{H}$, $J=5.0 \mathrm{~Hz}, \mathrm{H}-6), 6.85-7.32(\mathrm{~m}, 8 \mathrm{H}, P h) .{ }^{13} \mathrm{C}$ NMR $(100$ $\left.\mathrm{Hz}, \mathrm{CDCl}_{3}\right) \delta 15.3,16.4,17.5,17.7,19.3,19.4,20.5,20.7$, 20.8, 20.9, 22.7 25.7, 26.1, 29.7 (2 C), 29.9, 31.4, 31.9, 32.1, 32.2, 36.9, 37.3, 38.6, 39.9, 40.6, 41.3, 47.5, 50.1, 55.3 (2 C), 56.5, 62.5, 69.2, 69.3, 69.5, 70.1, 70.3, 70.4, 70.8, 72.3, 72.9 (2 C), 74.6, 74.9, 75.0, 76.0, 79.0, 81.9 (2

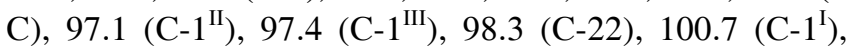
121.7 (C-6), 140.7 (C-5), 159.1 (2 C), 169.7 (2 $\left.\mathrm{CH}_{3} \mathrm{CO}\right)$, $169.8\left(2 \mathrm{CH}_{3} \mathrm{CO}\right), 170.2\left(\mathrm{CH}_{3} \mathrm{CO}\right), 170.3 \quad\left(\mathrm{CH}_{3} \mathrm{CO}\right)$. ESI-HRMS calcd for $\mathrm{C}_{73} \mathrm{H}_{101} \mathrm{NO}_{23}: 1359.6764[\mathrm{M}]^{+}$, found: $1360.6838[\mathrm{M}+\mathrm{H}]^{+}$.

\section{Synthesis of compound 1}

A solution of $13(30 \mathrm{mg}, 0.02 \mathrm{mmol})$ in TFA: $\mathrm{CH}_{2} \mathrm{Cl}_{2}$ $(1: 4, V / V, 1 \mathrm{~mL})$ was stirred at $-15^{\circ} \mathrm{C}$ for $0.5 \mathrm{~h}$, neutralized with saturated aqueous sodium bicarbonate, and extracted with dichloromethane $(3 \times 15 \mathrm{~mL})$. The organic phases were combined, dried over anhydrous sodium sulfate and concentrated, which was used in the next step without further purification. To a solution of the above residue in a mixed solvent $\left(5 \mathrm{~mL}, \mathrm{CH}_{2} \mathrm{Cl}_{2}: \mathrm{MeOH}=1: 3\right)$ aqueous $0.3 \mathrm{M}$ $\mathrm{NaOH}$ was added until the $\mathrm{pH}$ was 10 . The mixture was stirred at room temperature for $6 \mathrm{~h}$, and neutralized with
Amberlite IR-120 $\left(\mathrm{H}^{+}\right)$. The solvents were filtered, and the filtrate was concentrated to dryness under diminished pressure. The residue was subjected to column chromatography on silica gel with $5: 2 \mathrm{CH}_{2} \mathrm{Cl}_{2}-\mathrm{MeOH}$ as the eluent to yield 1 as a white solid $(15.7 \mathrm{mg}, 80 \%$ for 2 steps $) ;[\alpha]_{\mathrm{D}}{ }^{25}-88(c 0$. 5, $\left.\mathrm{MeOH}: \mathrm{CHCl}_{3}=1: 1\right)$ [lit. [4] $[\alpha]_{\mathrm{D}}{ }^{24}-91$ (c 0. 2, MeOH: $\left.\mathrm{CHCl}_{3}=1: 1\right)$ ]; The diagnostic NMR signals are identical to those reported for the natural product [1]. Selected ${ }^{1} \mathrm{H}$ NMR $\left(400 \mathrm{~Hz}, \mathrm{CDCl}_{3}: \mathrm{CD}_{3} \mathrm{OD}=1: 1\right): \delta 0.84(\mathrm{~s}, 3 \mathrm{H}$, $\mathrm{H}-18), 0.87$ (d, 3H, $J=6.2 \mathrm{~Hz}, \mathrm{H}-27), 0.97$ (d, 3H, $J=7.0$ $\mathrm{Hz}, \mathrm{H}-21$ ), 1.05 (s, 3H, H-19), 1.22-1.26 (m, 6H, H-6 ${ }^{\mathrm{II}}$, $\left.6^{\mathrm{III}}\right), 1.42-2.47(\mathrm{~m}, 24 \mathrm{H}), 2.63-2.67(\mathrm{~m}, 2 \mathrm{H}, \mathrm{H}-26)$, 3.21-4.09 (m, 15H), 4.31-4.33 (m, 1H, H-16), 4.50 (d, $\left.1 \mathrm{H}, J=7.8 \mathrm{~Hz}, \mathrm{H}-1^{\mathrm{I}}\right), 4.90\left(\mathrm{~s}, 1 \mathrm{H}, \mathrm{H}-1^{\mathrm{II}}\right), 5.24(\mathrm{~s}, 1 \mathrm{H}$, $\left.\mathrm{H}-1^{\mathrm{III}}\right), 5.40(\mathrm{~d}, 1 \mathrm{H}, J=4.0 \mathrm{~Hz}, \mathrm{H}-6)$. Selected ${ }^{13} \mathrm{C}$ NMR $\left(100 \mathrm{~Hz}, \mathrm{CDCl}_{3}: \mathrm{CD}_{3} \mathrm{OD}=1: 1\right): \delta 15.6,16.9,17.4,17.9$, 19.2 (2 C), 20.8, 28.4, 28.7, 29.2, 29.6, 30.2, 31.5, 33.4, 36.2 , 38.2, 39.1, 40.5, 41.5, 42.1, 47.3, 51.1, 56.0, 61.4, $62.8,68.2,68.9,69.2,69.4,70.5,71.5,73.3,73.5,75.5$, 76.8, 77.1, 79.1, 79.5, 79.6, 98.8, 100.4, 101.3, 102.4, 121.8, 141.3. ESI-HRMS calcd for $\mathrm{C}_{45} \mathrm{H}_{73} \mathrm{NO}_{15}: 867.4980$ $[\mathrm{M}]^{+}$, found: $868.5053[\mathrm{M}+\mathrm{H}]^{+}$.

\section{Results and discussion}

In our previous method [8], although treatment of solasodine $\mathbf{3}$ with a partially protected glycosyl donor $\mathbf{2}$ in dry methylene dichloride in the presence of AgOTf and $\mathrm{N}$-iodosuccinimide (NIS) at $-50{ }^{\circ} \mathrm{C}$ afforded the desired key saponin 4 in an optimized yield around 65\% (Scheme 1), significantly simplifying the solamargine synthesis, a large amount of expensive donor $\mathbf{2}$ was quickly consumed in the presence of cyclic amine (oxaza-spiro structure). Based on the phenomenon, herein we explored a new method for the total synthesis of solamargine $\mathbf{1}$ as shown in Scheme 2. First glycosylation before $N$-cyclization would favor synthesis of the desired molecule.

PMB (p-methoxybenzyl) in Schmidt reagent 5 was selected as the protecting groups, as it not only enhances the reactivity of the sugar moiety, but also improves the selectivity in the final deprotection step. Thus, the known compound 2 [8] was first acetylated with acetic anhydride in pyridine, which was further converted into trichloroacetim-

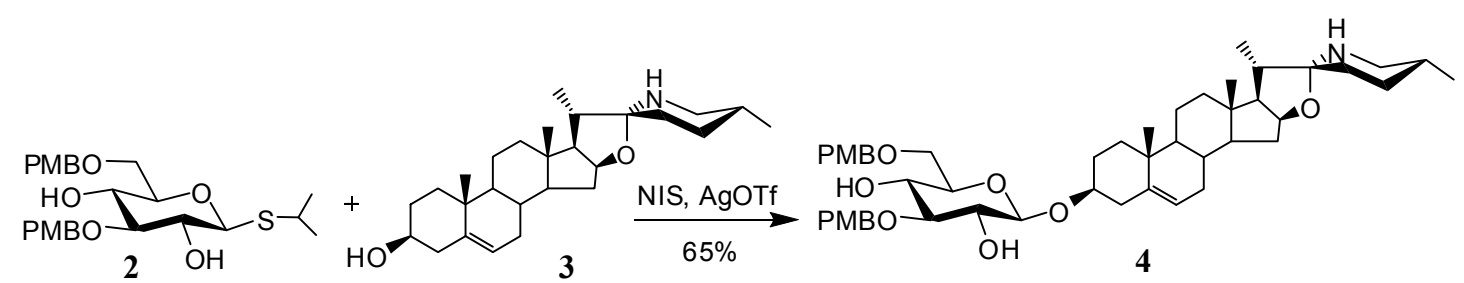

Scheme 1 The previous method of synthesis of Solamargine 1. 


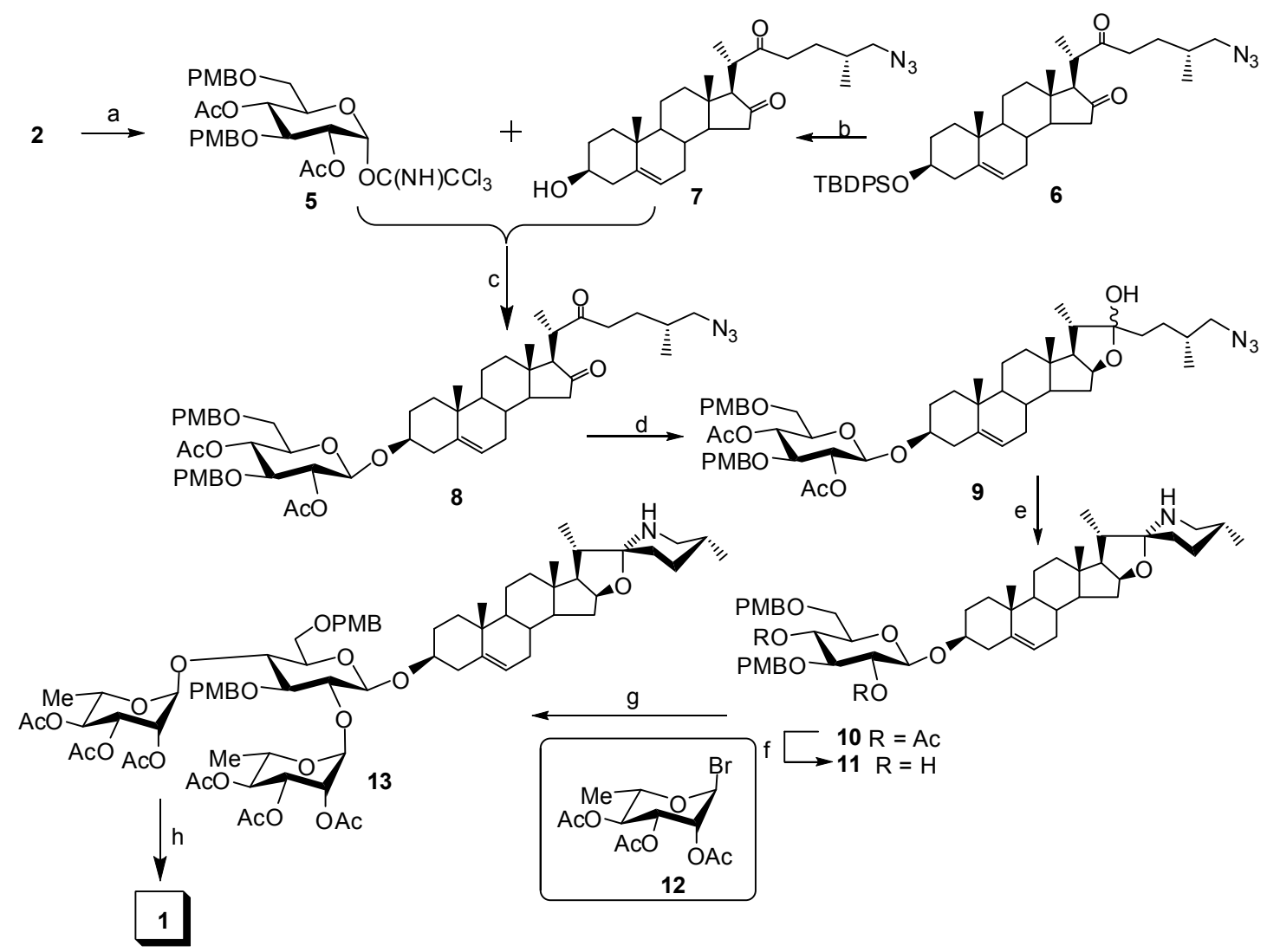

Scheme 2 Reagents and condition: (a) $\mathrm{Ac}_{2} \mathrm{O}$, Pyridine; NBS, wet DCM, dark, $0{ }^{\circ} \mathrm{C}$; DBU, $\mathrm{Cl}_{3} \mathrm{CCN}, \mathrm{DCM}, 88 \%$ (for 3 steps); (b) $\mathrm{HF} / \mathrm{Py}, 85 \%$; (c) $\mathrm{AgOTf}$, DCM, $-40^{\circ} \mathrm{C}, 94 \%$; (d) $\mathrm{NaBH}_{4}, i-\mathrm{PrOH}$, rt; (e) $\mathrm{Ph}_{3} \mathrm{P}, \mathrm{THF} / \mathrm{H}_{2} \mathrm{O}$ (v/v, 10:1), reflux; (f) $\mathrm{NaOMe}, \mathrm{MeOH}, 53 \%$ overall yield for three steps from 4; (g) 12 , AgOTf, 2,6-lutidine, DCM, $-30^{\circ} \mathrm{C}, 90 \%$; (h) $10 \% \mathrm{TFA}$ in DCM, $-15^{\circ} \mathrm{C} ; 0.3 \mathrm{M} \mathrm{NaOH}, \mathrm{MeOH}, 80 \%$ for 2 steps.

idate 5. Treatment of compound 6 [8] with HF/Py complex provided acceptor 7. After coupling of glycosyl donor $\mathbf{5}$ and aglycone precursor $\mathbf{7}$ in anhydrous methylene chloride with mild catalyst AgOTf [9], key intermediate 8 was obtained in 94\% isolated yield. Selective reduction of 16-ketone 8 with $\mathrm{NaBH}_{4} / i-\mathrm{PrOH}[10](\rightarrow \mathbf{9})$, followed by reductive cyclization with $\mathrm{Ph}_{3} \mathrm{P} / \mathrm{THF} / \mathrm{H}_{2} \mathrm{O}$ under refluxing $(\rightarrow \mathbf{1 0})$ and removal of the acetyl group with $\mathrm{NaOMe}$ in $\mathrm{MeOH}$, afforded acceptor $\mathbf{1 1}$ in $53 \%$ overall yield for three steps [8]. Condensation of $\mathbf{1 1}$ and rhamnopyranosyl bromide $\mathbf{1 2}$ using AgOTf and 2,6-lutidine as catalysts [11] afforded trisaccharide alkaloid $\mathbf{1 3}$ in excellent yield (90\%). Removal of the PMB groups of 13 with $10 \%$ TFA in DCM at $-15{ }^{\circ} \mathrm{C}$, followed by deacetylation with $0.3 \mathrm{M} \mathrm{NaOH}$ in $\mathrm{MeOH}$, afforded the final solamargine $\mathbf{1}$ in $80 \%$ overall yield for 2 steps [8]. The analytic data (NMR, MS, optical rotation) for the synthesized solamargine $\mathbf{1}$ were identical to those of the natural product $[1,8]$.

\section{Conclusion}

In summary, a highly efficient approach for the synthesis of solamargine $\mathbf{1}$ has been developed. First glycosylation be- fore $N$-cyclization significantly facilitated synthesis of the desired molecule. We anticipate that this work will provide a new approach to access solamargine and its diversified analogues.

This work was supported partially by the National Basic Research Program of China (2011CB936001) and National Natural Science Foundation of China (20732001, 20872172, 21072217).

1 Wanyonyi AW, Chhabra SC, Mkoji G, Eilert U, Njue WM. Bioactive steroidal alkaloid glycosides from Solanum aculeastrum. Phytochemistry, 2002, 59: 79-84

2 Kuo KW, Hsu SH, Li YP, Lin WL, Liu LF, Chang LC, Lin CC, Lin $\mathrm{CN}$, Sheu HM. Triggering apoptosis in human hepatoma cells. Biochem Pharmacol, 2000, 60: 1865-1873

3 Liu LF, Liang CH, Shiu LY, Lin W L, Lin CC, Kuo KW. Action of solamargine on human lung cancer cells--enhancement of the susceptibility of cancer cells to TNFs. FEBS Letters, 2004, 577: 67-74

4 Al Chami L, Méndez R, Chataing B, O'Callaghan J, Usubillaga A, LaCruz L. Toxicological effects of solamargine in experimental animals. Phytother Res, 2003, 17: 254-258

5 Maruo VM, Soares MR, Bernardi MM, Spinosa HS. Embryotoxic effects of Solanum lycocarpum St. Hill fruits consumption during preimplantation and organogenesis in rats. Neurotoxicol Teratol, 2003, 25: 627-631

6 Heo KS, Lee SJ, Ko JH, Lim K, Lim KT. Glycoprotein isolated from Solanum nigrum L. inhibits the DNA-binding activities 
of NF-kappaB and AP-1, and increases the production of nitric oxide in TPA-stimulated MCF-7 cells. Toxicol in Vitro, 2004, 18: 755-763

7 Shahid M. Synthesis of solanum glycosides. PCT Patent WO/018604, 2003

8 Wei G, Wang J, Du Y. Total synthesis of solamargine. Bioorg Med Chem Lett, 2011, 21: 2930-2933

9 Wei G, Gu G, Du Y. Silver Triflate. A mild alternative catalyst for glycosylation conditions using trichloroacetimidates as glycosyl donors. J Carbohydr Chem, 2003, 22: 385-393

10 Mazur Y, Danieli N, Sondheimer F. The synthesis of the steroidal sapogenins. J Am Chem Soc, 1960, 82: 5889-5908

11 Depré D, Düffels A, Green LG, Roman L, Ley SV, Wong C-H. Synthesis of glycans from the glycodelins: two undeca-, two deca-, three nona-, an octa-and a heptasaccharide. Chem Eur J, 1999, 5: 33263340 